\title{
Sosyal Etkileşim Alanı Olarak Üniversite Kampüsünde Tasarlanan Kafeterya; Green House
}

\author{
Hasan POLAT ${ }^{*}$, Nihal Arda AKYILDIZ ${ }^{2}$ \\ ${ }^{1}$ Mimarlık Bölümü, Mimarlık Fakültesi, Fırat Üniversitesi, Elazı̆̆, Türkiye \\ ${ }^{2}$ Mimarlık Bölümü, Mimarlık Fakültesi, Fırat Üniversitesi, Elazığ, Türkiye \\ ${ }^{* 1}$ hpolat@ firat.edu.tr, ${ }^{2}$ nihalardaa@ hotmail.com
}

Öz: Sosyal yaşam için mekân düzenleme çeşitliliklerine alternatif olarak planlanan kafeteryalar, toplumsal hayata sunduğu etkileşim ve iletişim ortamlarıyla önemli katkı sunmaktadır. Her toplumun bulunduğu coğrafya, gündelik yaşam talepleri, kültürel ve sosyal yapıya bağlı olarak biçimlenen kafeler açık ve kapalı mekân alternatifleriyle hemen her yaş grubu için sosyal yaşamımızın her seviyesinde toplumsal yaşamımızın ayrılmaz parçalarıdır. Çalışma konumuz olan kafeteryaların üniversite kampüslerinde pek çok kültür, etnik yapı ve düşünceye sahip genç yaş grubunun sosyal hayatını yakından etkileme kapasitesi nedeniyle incelenmiş olup, Fırat Üniversite kampüsü için projelendirilmiş ve uygulanmıştır. Kampüs içinde doğal çevresiyle birlikte tasarlanması gereken gündelik yaşamda etkileşim, karşılaşma ve kaynaşma araçsallarından olan kafeteryaların, kampüsün doğal çevresine saygılı, kampüs kullanıcılarının taleplerini karşılayabilecek proje sunumuyla konuya katkı sağlamak hedeflenmiştir.

Anahtar kelimeler: Tüketim Alışkanlığı, Kafeterya, Üniversite Kampüsü, Sürdürülebilirlik, Ekolojik Mekânsal Tasarım.

\section{A Cafeteria Designed as a Field of Social Interaction in the University Campus; Green house}

\begin{abstract}
Cafeterias, planned as an alternative spatial arrangement for social life, make an important contribution to the social life through the interaction and communication environments. The geography of every society, the demands of daily life, the cafes shaped depending on the cultural and social structure are indispensable parts of our social life at every level of our social life for almost every age group with open and closed alternatives.

The cafeterias, which are the subject of our study, have been studied and applied for the campus of Firat University because of their capacity to closely affect the social life of the young age group with many cultures, ethnicities and thoughts in the university campuses. In the campus, it is aimed to contribute to the subject with the project presentation which will be able to meet the demands of the campus users.
\end{abstract}

Key words: Consumption habits, cafeteria, university campus, sustainability, ecological spatial design

\section{Giris}

Mekân tasarım yapılan alan çevresini bazen sınırlayarak, bazen de yeniden tanımlayarak yeni bir işlev ve fonksiyon vererek kendine ait ontolojisini gerçekleştirir. Harvey’e göre, mekân bir olgu olarak ele alındığında, maddeden ayrı bir "kendinden şey" haline gelir; böylece ayırt edici ve sınıflandırıcı bir yapıya dönüşür [1]. Aslında mekân tasarlandıktan sonra artık çevresini yeni bir anlama dönüştürür.

Günümüzde değişen toplumsal yapıyla birlikte mekân fonksiyonları, talepleri ve mekân kullanım alışkanlıkları da büyük değişimler yaşamıştır. Yirminci yüzyılla başlayan yeni modernleşme anlayışı tüketici toplum alışkanlıklarını yaratmış ve mekânsal talepler de bu anlamda evrilmiştir. Tüketici toplum anlayışının sosyal etkisi yaratıcı bir süreç olarak, hem sosyal ilişkilerde hem de kültürde yeni değerlerin ortaya çıkmasında etkili olmuştur. Toffler'e göre değişen dünyada post modern dalganın temel özellikleri olan parçalanma ve bireyselleşmenin artan değişim hızıyla insanlar için; tüketim alışkanlıkları ve mimari mekânların anlamları da “tüketiliyor” [2]. Jencks'e göre post modern dönemin özellikleri, küresel görünüme yönelik post modernizm tadıyla kültür ve türe bağlı olarak çokuluslu, çoğulcu eklektik ve kapsayıcılıkla döngüsel modelde hızlı bir değişme gücüdür [3]. Bu anlamda ele alındığında tüm kavramlar gibi mekân kavramı da bir metafordan ibaret olmayıp, siyasî erklerin, küreselleşme tasavvurlarını hayata geçirmek için yapılan operasyonlar olarak, toplumlarda çarpıcı bir biçimde görünür hale gelmiştir [4].

Küreselleşen dünyada hemen her ülkede zincirler halinde aynı dekorasyon kararlarıyla tasarlanan kafeler, günümüzde Adorno'un da değindiği 'kültürün her şeye benzerlik bulaştırma özelliğiyle'[5] sosyal yaşam

\footnotetext{
* Sorumlu yazar: hpolat@ firat.edu.tr. Yazarların ORCID Numarası: ${ }^{1}$ 0000-0002-4935-0111, ${ }^{2}$ 0000-0003-1948-188X
} 
taleplerimizi de benzer biçimlerde yapılandırmaktadır. Böyle bir ortamda gerçekleşen yaşam tarzı, değerlerin gerekçesiz olarak ihmal edilmesine neden olan bir değişimle adeta simülasyon yaşamaktadır. Bir meta olarak tüketim nesnesi yalnızca değer ve değişime sahip değildir. Ahlava'nın da değindiği, böyle bir tüketici toplumda bir metanın işaret ve sembol değerlerine sahip olması ve onu belirleyen kod mitle ilişkili olması onu daha faydalı ve değerli kılmaktadır[6]. Günümüzde bu semboller mekânların fonksiyonlarına, anlamlarına da hükmetmektedir.

\section{Tüketim Alışkanlığının Mekânsal Tasarıma Etkileri}

Farklı yaşam tarzları ve kültürler, farklı türlerde yiyecek tüketme davranışlarına yol açmıştır. Bu yiyecek tüketim davranışı eğlence, ruh durumu ve popüler eğilimden çok daha fazlası olmuştur [7] . Başlangıçta ev içi bir faaliyet olan ancak liberal ekonomilerle birlikte evin dişında da gerçekleşen yiyecek tüketimi; zevk almak için zaman harcama ve eğlence etkinliği haline gelmiştir. Özellikle yeşil alanlarla birlikte tasarlanan ekolojik mekânsal tasarım anlayışıyla planlanan kafeteryalar daha fazla rağbet görmektedir. Bu nedenle tüketim toplumu hemen her konuda taleplerini yenilerken gündelik yaşamımıza yeşille desteklenmiş mekanlar olabilen lokanta ve kafeteryaların yiyecek ve içecek taleplerimizi karşılayan alternatif alanlar olarak sosyal hayatımızı renklendirmektedir. Bu anlamda hizmet veren çeşitli alanlar; mekânsal boyut devingenlikten kaynaklı olarak, sayısız farklı yaşantılar üretebilme özelliğiyle, tasarımın 'n'inci boyut'undan söz etmeyi olanaklı kılmaktadır [8].

Sosyal bilimler açısından, tüketici toplum tarafından mekânların metalaştırılması konusundaki araştırmalar; yemek mekânıyla ilgili seçimlerin, fiziksel koşullar ve sosyal şartlardan güçlü bir şekilde etkilendiğini göstermektedir [9]. Günümüzde tüketim ürünlerini satın almak, kullanmak veya elden çıkarmak; hayal gücümüzün ötesinde bizi diğer insanlara ve diğer yerlere bir şekilde bağlar. Birçok birey için tüketim alışkanlığının yarattığı mekânsal düzlemler, çağdaş toplumda gündelik hayatın, hem görünür hem de yaygın bir parçasıdır. Bir kafeterya veya restoranda harcanacak zaman ve etkinlik, birçok insan için günlük yaşamın kabul görmüş bir yönü ve gündelik alışkanlığıdır. Ancak bu eylem, mekânın yaratılması ve ifade edilmesinde kritik bir rol oynar. Çağdaş bir toplum için hemen her coğrafyada tüketimin ve onun yarattığı mekânsal kararların nasıl oluştuğu, ifade edildiği ve yaşandığ konusu bu sektör için temel argüman olmuştur. Asıl konu, tüketimin kabul edilmesinin gerekliliğiyle birlikte mekân ve zaman içinde hangi düzlemlerce yaratıldığı, ifade edildiği ve anlam kazandığı olmuştur. Tüketim akışkan ve bağlamsal olduğundan mekânsal düzlemlerde de farklı ve düzensiz bir şekilde üretilir [10]. Yiyeceklerle ilgili tercihler geçici kişisel nitelikleri gösterebildiği gibi; seçilen restoran veya kafeler de kişilerin ruh durumlarını ifade etmektedir. Söz konusu mekânlar, sadece bireyler için değil, bazı şehirler için bile semboller olarak görülmektedir [7], özellikle de şehrin doğayla olan bağlarını destekleyen ekolojiye saygılı mekan alternatifleri hemen her kent için tercih edilen kafeterya ve lokantalar olmaktadır. Yemek yeme eylemi için seçilen yerler bize kendimiz ve bulunduğumuz durum hakkında bir şeyler söyleyebilir [11]. Doğal ekolojik çevresiyle birlikte tasarlanan bir kafeterya da kentin taleplerinin hala doğadan yana olduğunu ortaya koymaktadır.

Kafeteryalardaki mekânsal organizasyon ve tasarım kararları, yemek ve içecek için tasarlanan alandaki makine, ekipman, mobilya ve oturma düzeni gibi nesnelerin düzenlenme organizasyonunu da etkiler bu nedenle hepsi bir arada mekanı ifade eder. [12]. Yapılan yerleşim düzeni, gençlerin kalite algısı, mutluluk düzeyi ve dolaylı olarak tekrar aynı mekânı seçme isteği üzerinde bir etki yaratmaktadır. Bu nedenle, mekânı tasarlayanın ve işletenin, gençlerin kafeye tekrar gelme sıklığını artırabilmek için yemek ve içecek alanlarının konforuna ve organizasyonuna dikkat etmeleri önemlidir. Bu tarz tüketim mekânlarına -restoran, kafeterya vb- girildiğinde mekânın estetiği ve çekiciliği, mekânsal organizasyondaki uyuma dayanarak değerlendirmeyi amaçladığı için önemlidir. Gençler, yemek yeme mekânının estetik ve dekorasyonundaki cazibeyi gözlemlemek, hissetmek ve değerlendirmek için saatlerini harcayabilmektedir. Bu değerlendirmedeki kanaatleri onların yemek ve içeceklere yönelik tutum ve değerlendirmelerini bile etkilemesi muhtemeldir [13]. Bu nedenle tasarım ve dekorasyondaki herhangi bir eksiklik gençlerin kendilerini rahatsız hissetmelerini sağlayabildiği gibi, çekici bir ortamın yarattığ benzersiz bir atmosfer de mekânın tercih edilebilme kapasitesini artırarak tercihleri belirler. Kivela bu nedenle gençlerin mekân tercihlerinin bu tür mekânsal organizasyonlardaki estetikle koşut oluştuğunu [14] ve onları yer seçme konusunda da etkilediğini ifade etmektedir.

\section{3. Üniversite Kampüs Kafeteryası; Green House}

Green House, Elazı̆̆ Fırat Üniversitesi Mühendislik Kampüsü içinde doğal çevreye saygılı ekolojik mekan anlayışını referans alan bir kafeterya tasarlanmış ve şu an üniversite gençlerinin severek sıklıkla kullandıkları bir mekân olarak işlevini sürdürmektedir. Kafeterya 'Green House' adını etrafını saran üniversitenin doğal yeşil çevresi nedeniyle almıştır. Proje kurgusu ve tasarımı tamamen doğa ile uyum fikrini esas almış ekolojinin insan ve doğa bağını sürdürmeyi hedeflemiştir. Proje tasarımına başlamadan yapının yapılacağı alanın hâlihazır alımı yapılarak mevcut ağaçlar dwg ortamına aktarılarak, bütün ağaçların korunması sağlanmıştır. Yapı kütlesinin 
formu, tamamen doğaya saygı çerçevesiyle mevcut ağaçların izin verdiği ölçüde planlanmış ve ortamın ekolojisine göre şekil almıştır (Şekil 1).

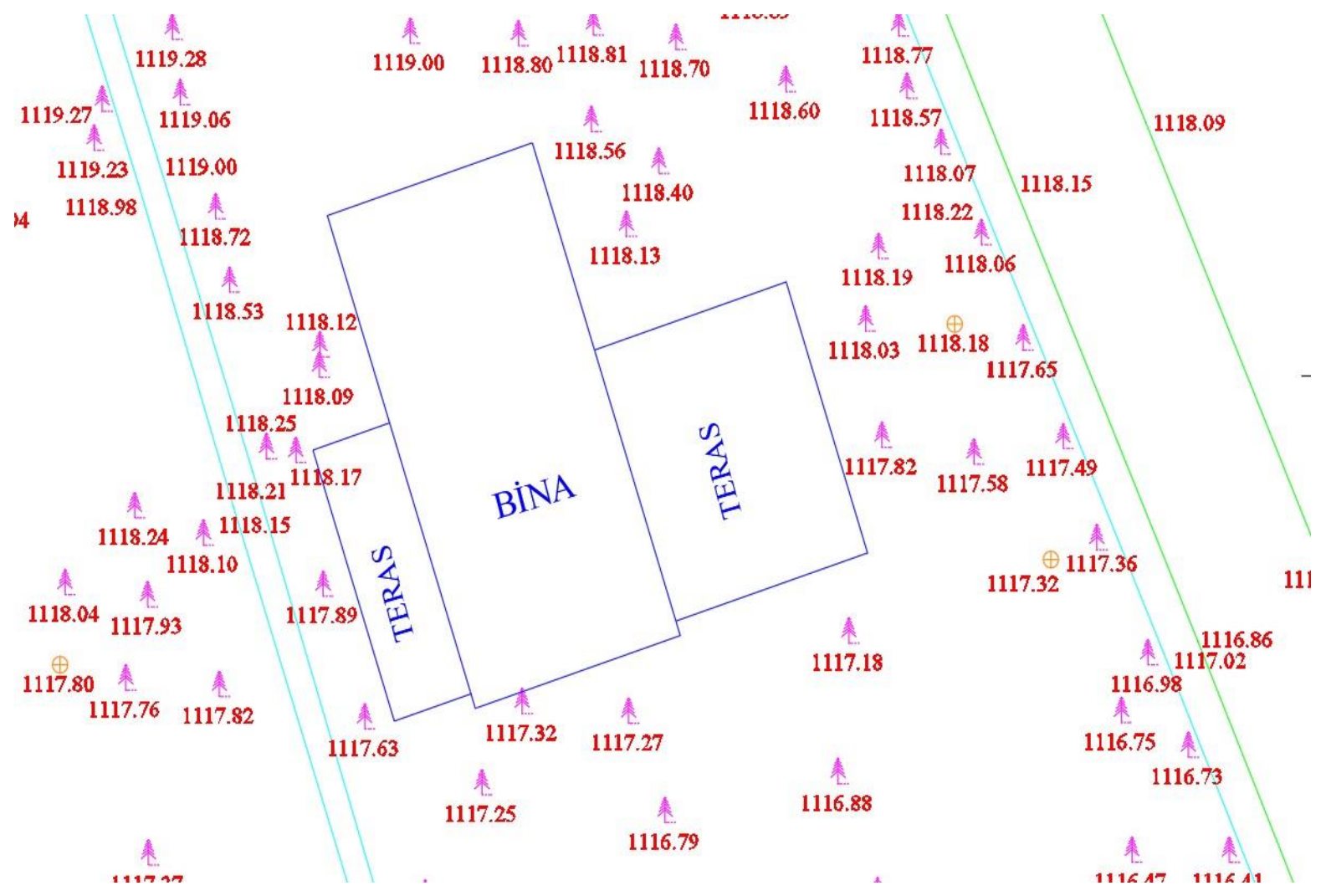

Şekil 1. Proje Alanı - Hâlihazır Haritası

Bina zemin ve birinci kattan ibarettir. Açık alan, yarı açık alan ve kapalı alan temelinde oluşan mekânlar basit geometrilerle oluşturulmuştur. Mekânsal düzenlemede, doğal yapısal çevreden maksimum faydalanarak mekân üretmek temel referans noktası olarak alındığından açık alanlarla kapalı alan ilişkisi pek çok noktada sağlanmış ve görsel temas da kesilmemeye gayret edilmiştir. Zemin katta sol yan cephe ve sağ yan cepheden servis alanına giriş yapılarak fonksiyon farklılı̆̆ ile kapalı oturma alanı ile mutfak alanı birbirinden ayrılmıştır. Böylelikle kapalı oturma alanında net kullanım alanı da elde edilmiștir. Kapalı oturma alanından yarı açık alanlara geçiş ve kullanılan alternatifli açık alanlar mevsim olanakları dâhilinde sağlanmıştır. Bu durum yarı açık alan ile kapalı alanın bütünlüğünü sağlamaktadır. Bina servisini sağlayan tüm mekânlar (mutfak, ıslak hacimler vb.) zemin katta çözülmüştür. Böylelikle birinci katta bir takım sosyal etkinliklerin yapılabileceği (doğum günü organizasyonları, canlı müzik, öğrenci toplantı ve etkinlikleri gibi) net bir alan elde edilmiş ve üniversitenin doğal yapısal çevresinin seyrinin mümkün olması için özen gösterilmiştir. Ayrıca birinci kat alanının önemli bir bölümü yapının etrafını saran yeşil ekolojik örtüsüyle (Şekil 2) birliktelik sağlayabilmek amacıyla yarı açık alan olarak tasarlanmıştır (Şekil 3). 


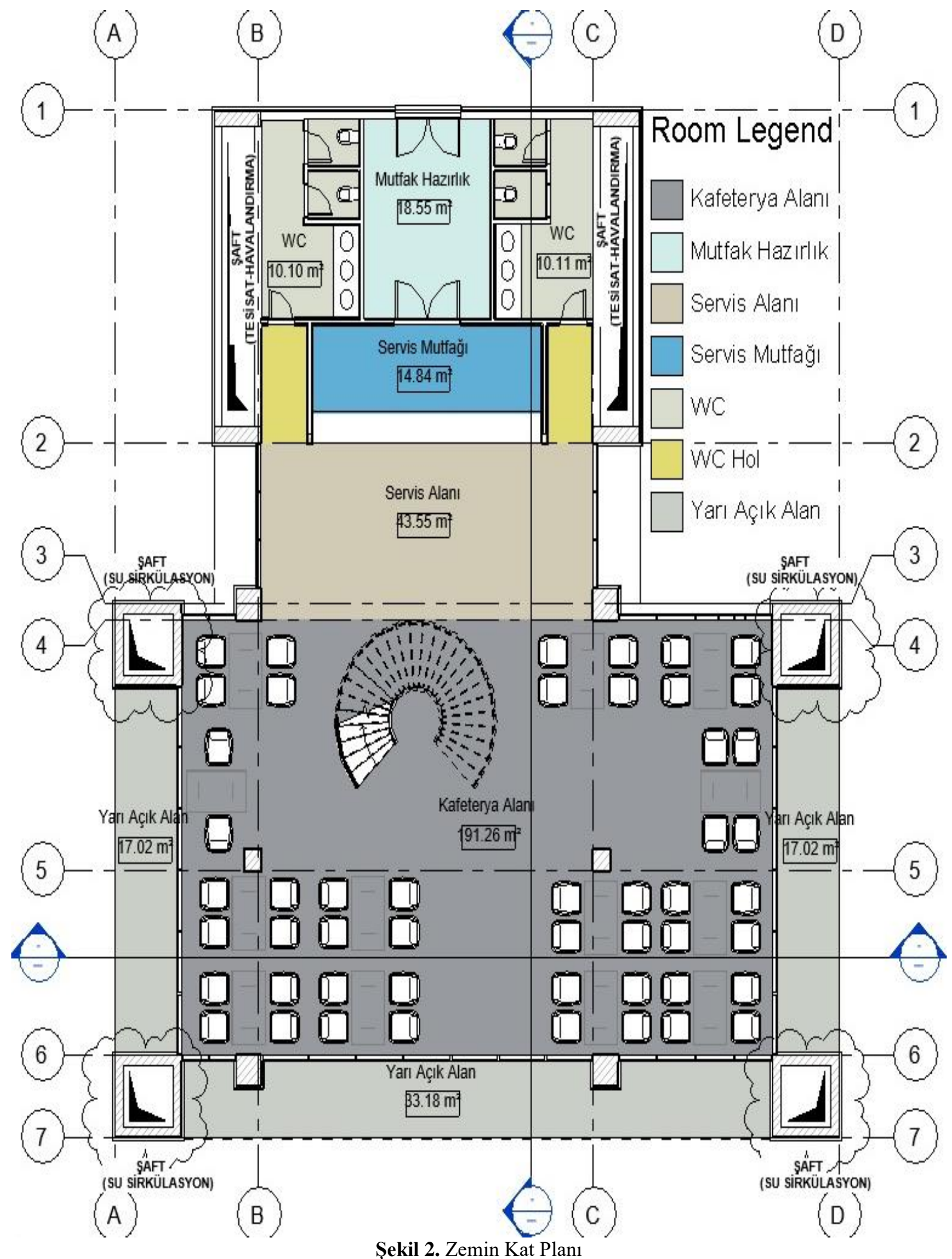

Zemin kat planında görülen su sirkülasyonu olarak belirtilen şaftlar (4 adet) 1.katın terasında yer alan yeşil elemanların ve terasta biriken suların doğal zemine aktarılmasını sağlamaktadır. Bu sayede su tahliyesi için 
dışarıdan iniş borusu yapılmasına gerek kalmamakla birlikte 1.kat terasında doğal bitki/ağaç ekimine olanak sağlanmıştır. Ayrıca bu şaftların çevrelediği alan doğal olarak zemin katta yarı açık alan oluşturmuştur.

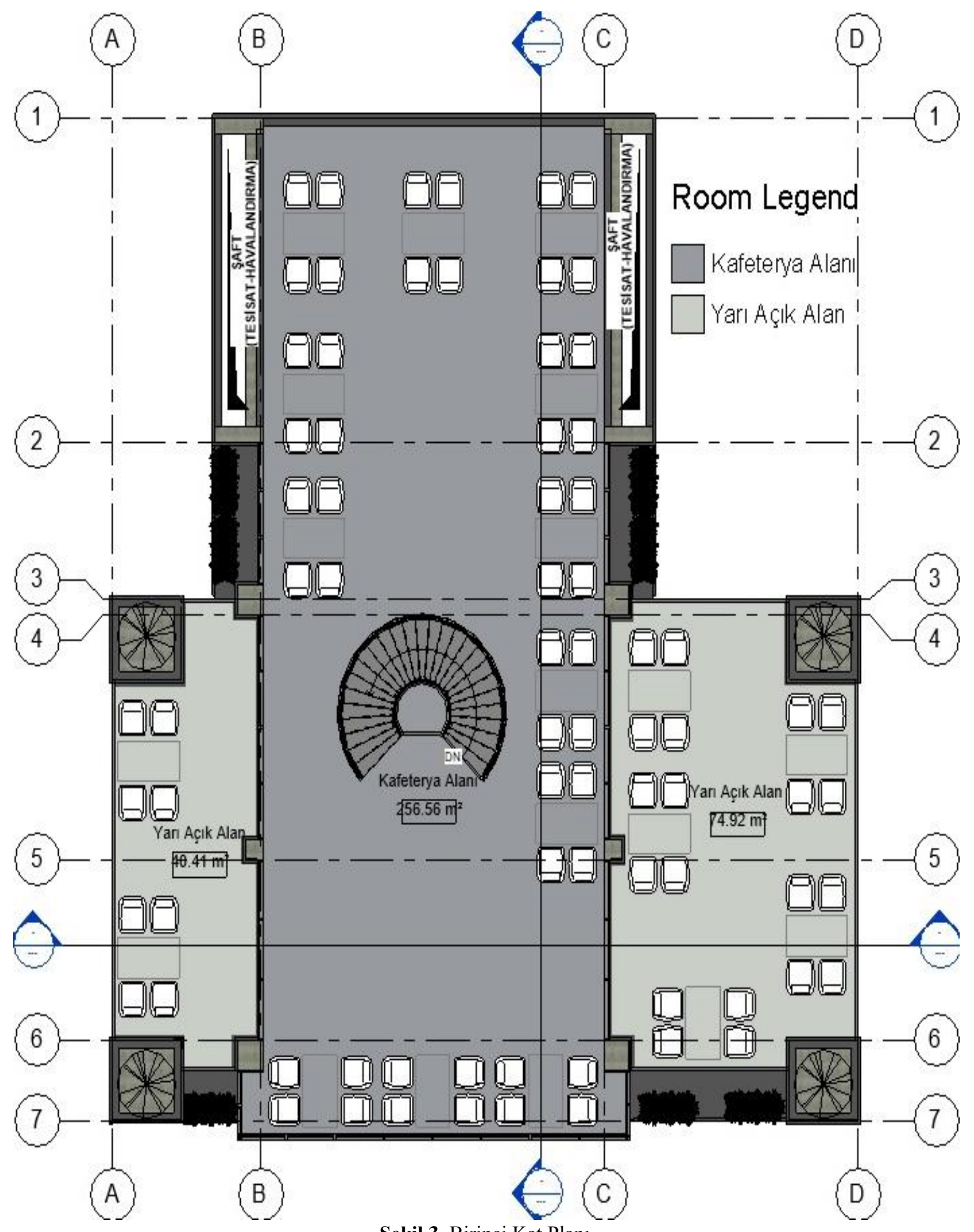

Şekil 3. Birinci Kat Planı 
Yap1 yüksekliği yine içinde bulunduğu ekolojik çevresindeki yeşil örtünün kotları gözetilerek 8.50 'de bitirilmiş böylece mekânsal tasarımda doğal yeşil çevre esas alınmıştır. Zemin katta brüt kat yüksekliği 5,00 mt (Şekil 4,), 1.katta ise 3,50mt dir (Şekil 5).

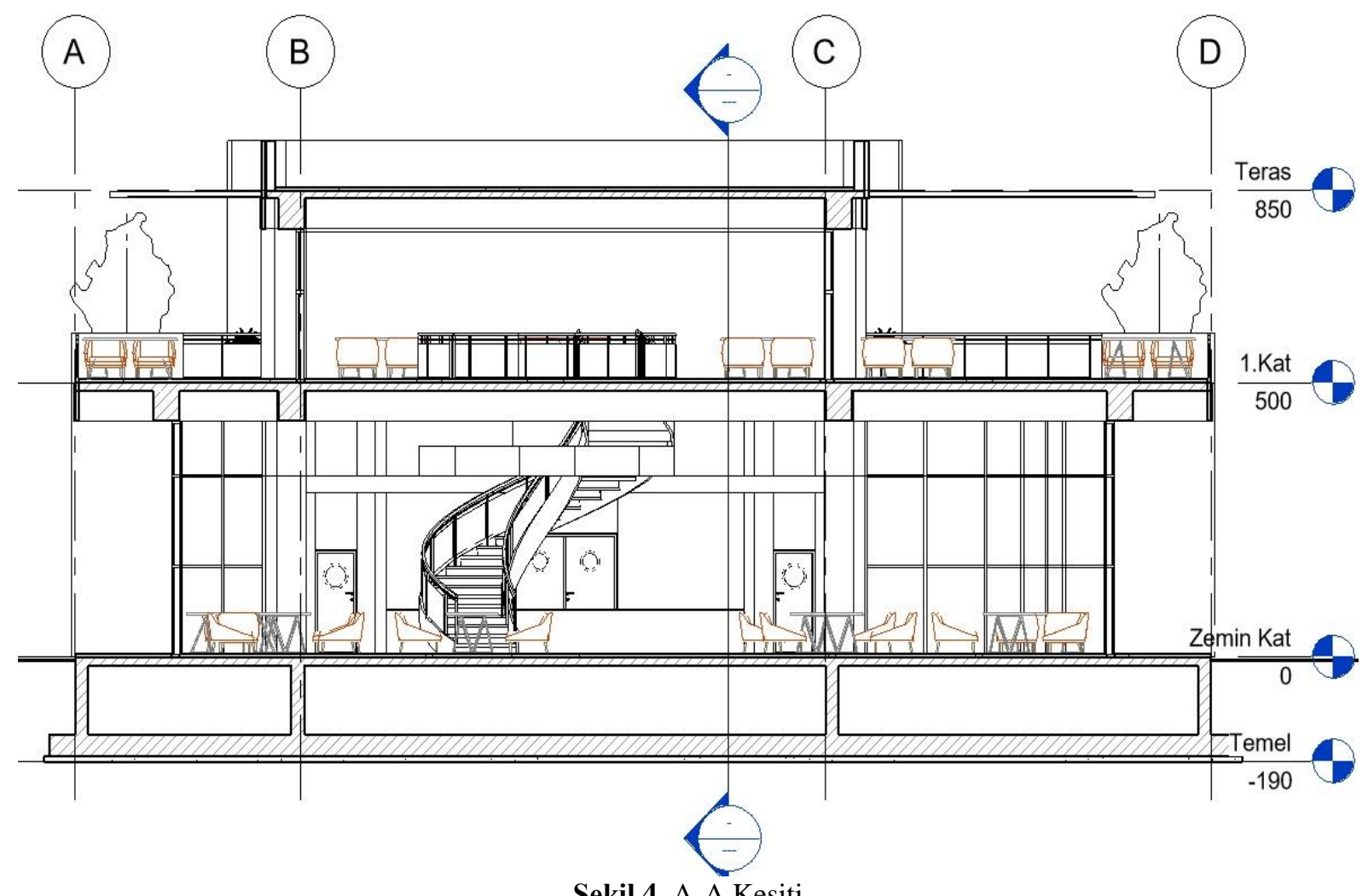

Şekil 4. A-A Kesiti

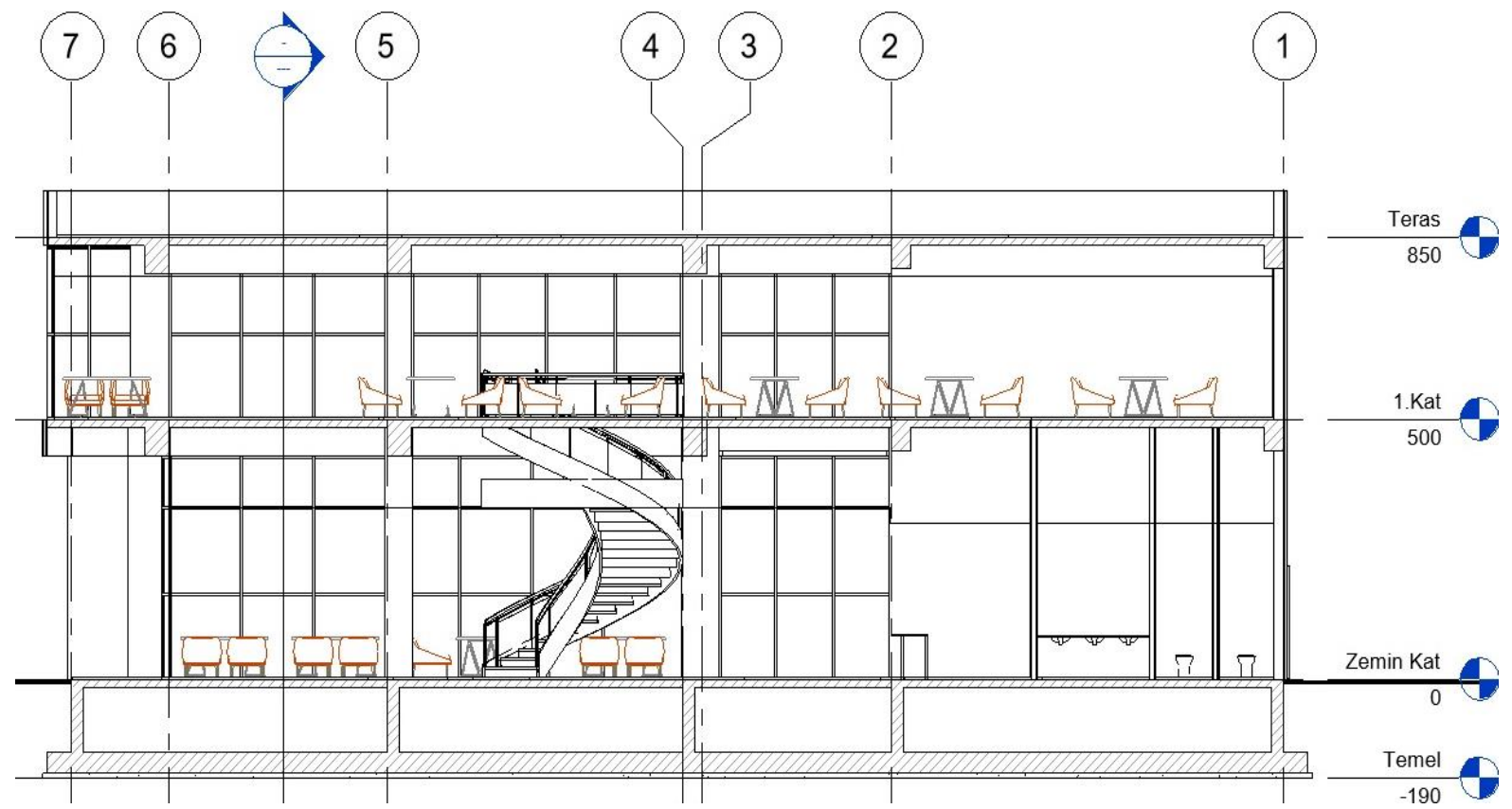

Şekil 5. B-B Kesiti 
Bina cephesi kurgulanırken güney (Şekil 6), doğu (Şekil 8) ve batıya (Şekil 9) yönlendirilen ön ve yan cephelerde şeffaf yüzeyler kullanılmıştır. Bu seçimde gün ışığının ve manzaranın etkisi önemli etkenlerdir. Kuzeye yönlendirilen arka cephede ise (Şekil 7) 1slak mekânlar konumlandırılarak masif yüzey elde edilmiştir. Böylelikle hem mahremiyet olgusu sağlanmış hem de 1sı kayıpları minimize edilmeye çalışılarak mekânsal tasarımda enerji tüketimi ve sürdürülebilirlik konularına da hassasiyet gösterilmiştir.

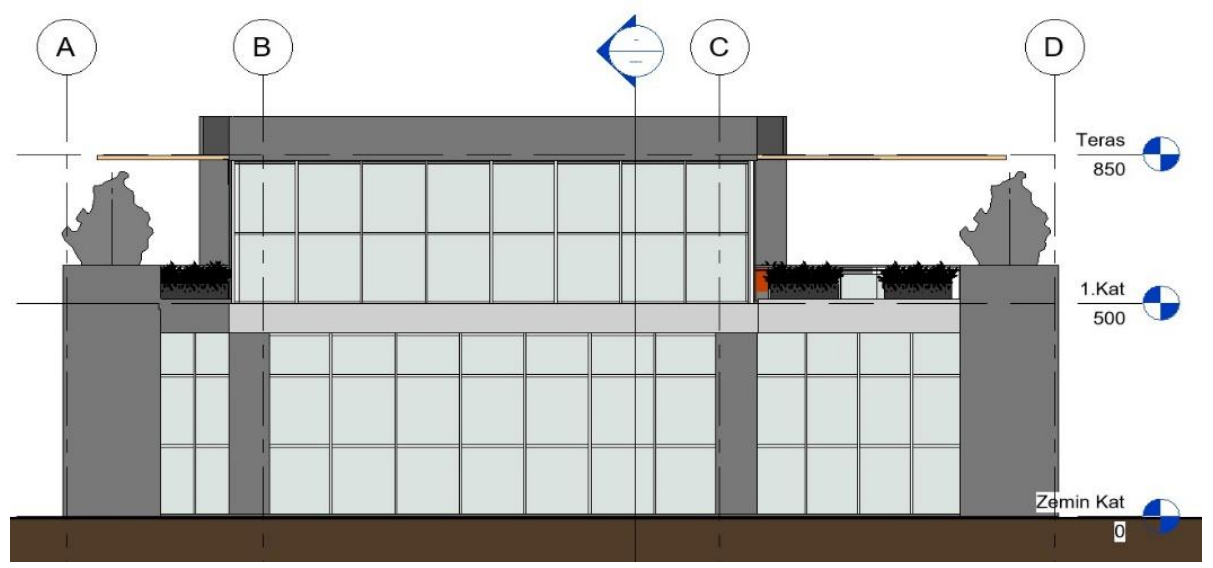

Şekil 6. Ön Görünüş

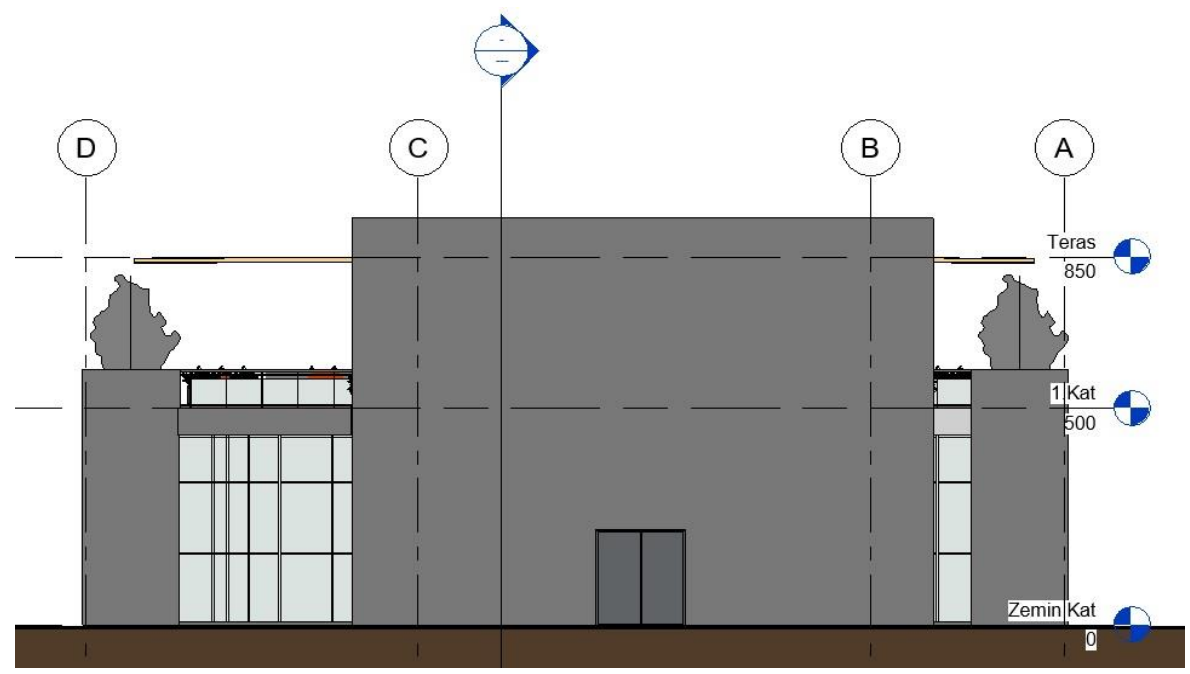

Şekil 7. Arka Görünüş

Görünüşlerde doğal yapısal çevreden maksimum faydalanabilmeyi esas alarak geniş şeffaf açıklıklarla tasarım yapılmış, enerji tüketimi ve mimari sürdürülebilirlik de dikkate alınarak cephe kararları verilmiştir. 


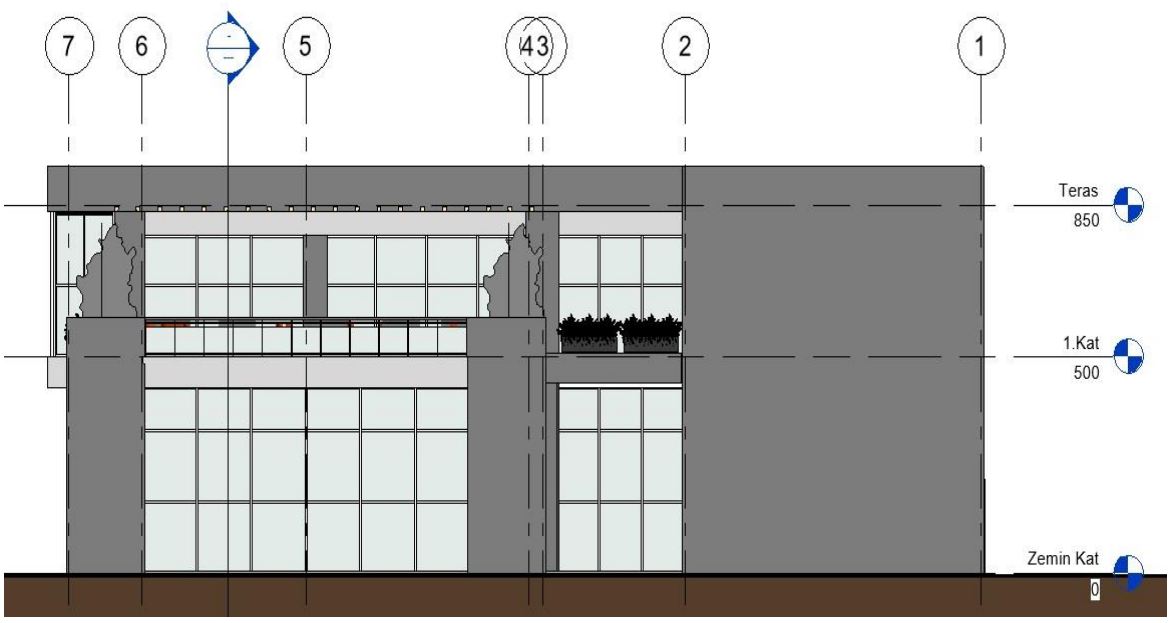

Şekil 8. Sağ Yan Görünüş

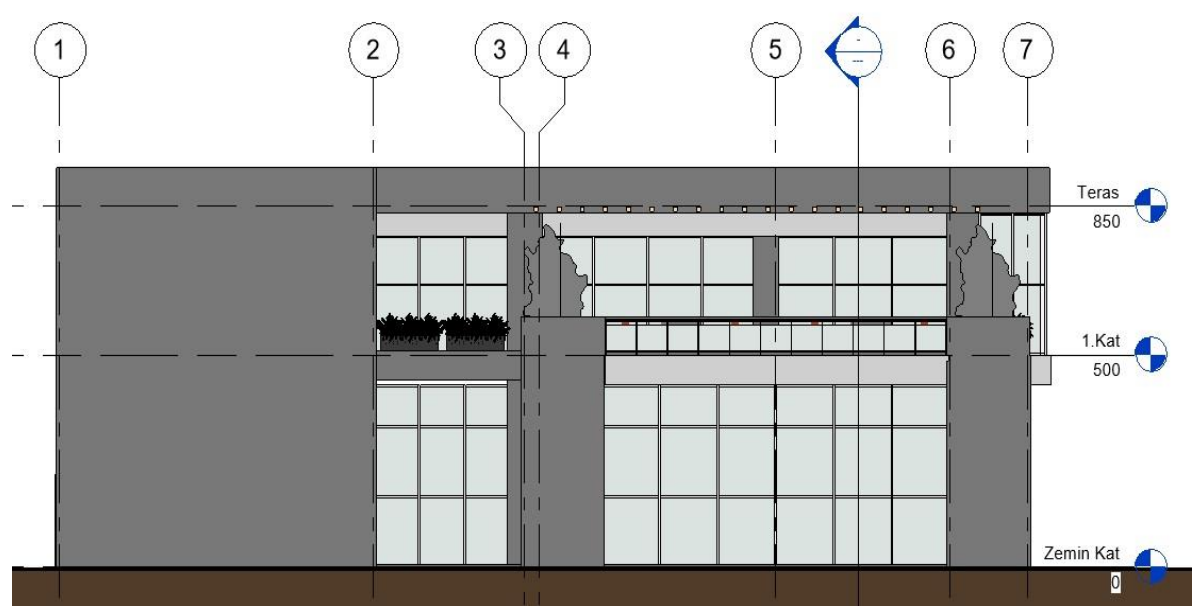

Şekil 9. Sol Yan Görünüş

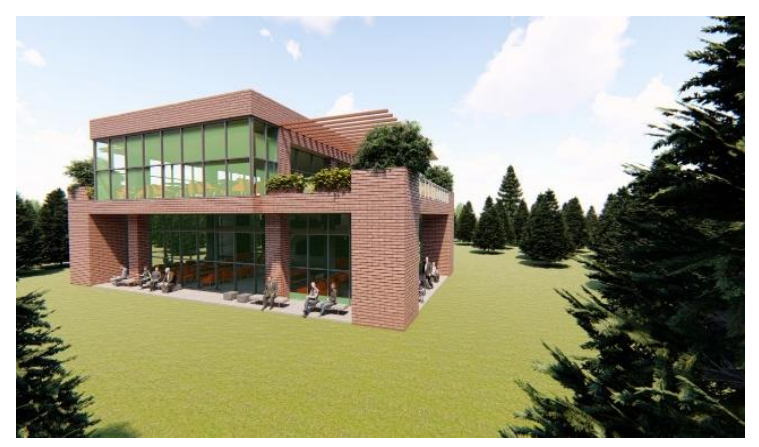

Şekil 10. Perspektifler a) güneydoğu

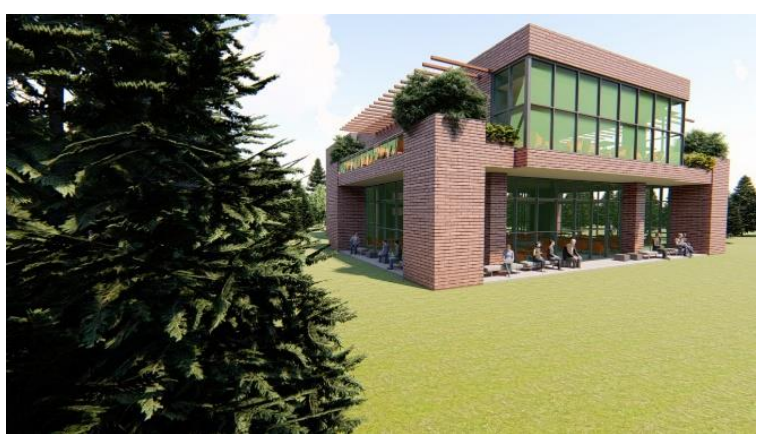

Şekil 10. Perspektifler b) güneybat1 


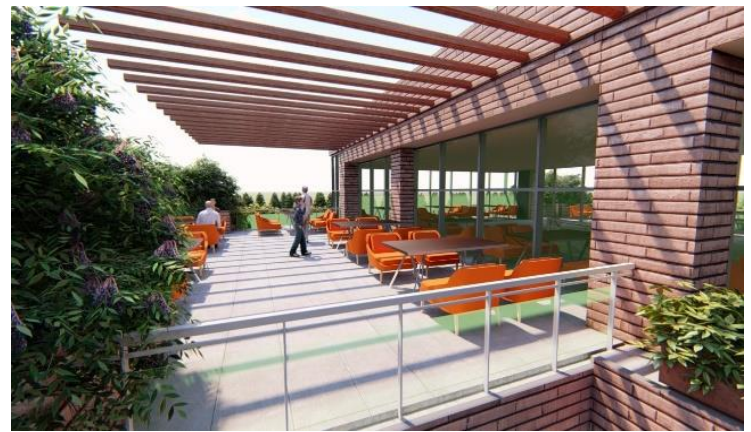

Şekil 11. Perspektifler a) üst teras

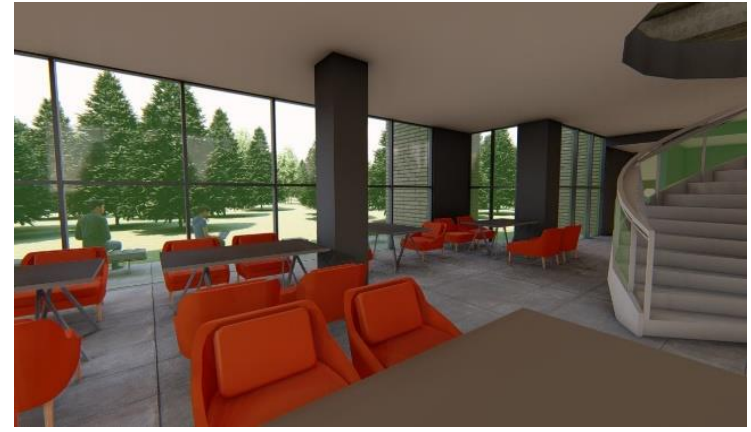

Şekil 12. Perspektifler a) iç mekân yerleşimi

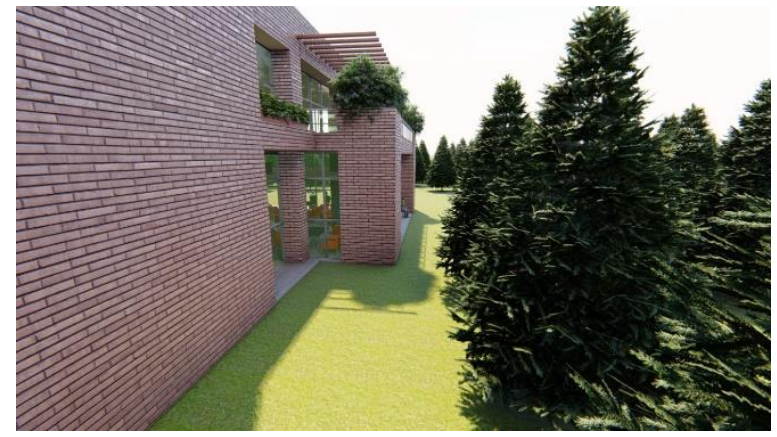

Şekil 11. Perspektifler b) bahçe terası

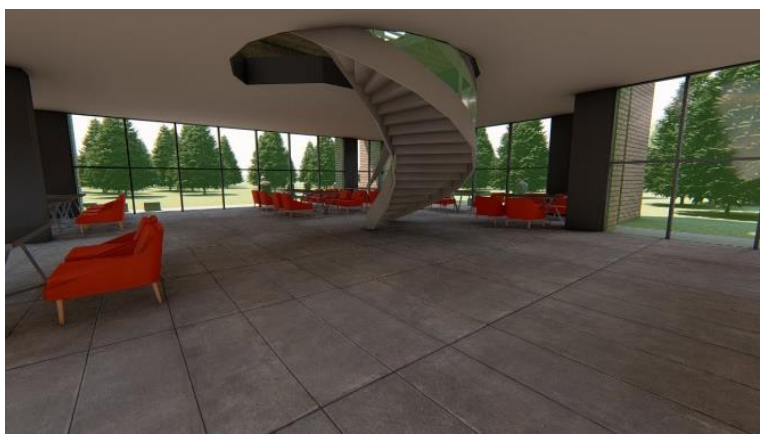

Şekil 12. Perspektifler b) iç merdiven

Perspektiflerden de anlaşıldığı gibi, üniversite gençleri için kaynaşma, karşılaşma ve etkileşim alanı olma niteliğiyle (Şekil 10 a ve b) green house; doğal çevresiyle simbiyotik bir ilişki kurarak (Şekil 11 a ve b) gençlerin psikolojik ve ruhsal yapılarına da destek olacak bir dinlenme ve etkinlik alanı olarak (Şekil 12 a ve b) fonksiyonunu başarıyla yürütmektedir.

\section{Proje Künyesi}

\subsection{Proje Nicelikleri ile İlgili Bilgiler}

Proje ihtiyaç programı işveren ile birlikte kullanıcı sayısı ve ekonomik olanaklar kapsamında tasarımcı ile birlikte hazırlanmıştır. Belirlenen ihtiyaç programı kapsamında kesin proje ve uygulama Tablo 1. de gösterildiği gibidir.

Tablo 1. Proje Alan Tablosu

\begin{tabular}{|l|l|l|l|}
\hline \multicolumn{1}{|c|}{ Kat Adı } & \multicolumn{1}{|c|}{ Kapalı Alanı (m2) } & \multicolumn{1}{|c|}{ Yarı Açık Alan (m2) } & Toplam Alan (m2) \\
\hline Zemin Kat & 304,00 & 41,00 & 345,00 \\
\hline 1.Kat & 260,00 & 85,00 & 345,00 \\
\hline Genel & $\mathbf{5 6 4 , 0 0}$ & $\mathbf{1 2 6 , 0 0}$ & $\mathbf{6 9 0 , 0 0}$ \\
\hline
\end{tabular}

\subsection{Proje ve Yapım Bilgileri}

Mimari Tasarım

Uygulama Projesi

Statik Proje

Mekanik Proje

Elektrik Projesi
: Hasan POLAT Dr. Mimar

: Hasan POLAT, Dr. Mimar - Adem FİL, Yapı Ressamı

: Miraç GÖKDOĞAN, İnşaat Mühendisi

: Çiğdem BOZDAĞ, Makine Mühendisi

: Erhan AZTEKIN, Elektrik Mühendisi 
$\begin{array}{ll}\text { İşveren } & : \text { Firat Üniversitesi Rektörlüğü } \\ \text { Kontrol } & : \text { Fırat Üniversitesi Yapı İşleri ve Teknik Daire Başkanlığı } \\ \text { Yüklenici } & : \text { Özcan ÇELIK } \\ \text { Sözleşme Tarihi } & : 21.05 .2014 \\ \text { Bitiş Tarihi } & : 12.05 .2015\end{array}$

\section{Sonuç ve Değerlendirme}

Günümüzün tüketim toplumlarında mekânsal tasarım estetikle desteklenmiş bir atmosferle planlanmaktadır. Tüketici bir toplumdaki mekânsal fikirler toplumsal taleplerle birlikte yeniden dizayn edilerek aslında mekânın yeniden anlamlanmasını sağlamaktadır. Tüketim alışkanlıklarının mekânsal tasarım çeşitliliğine sunduğu katkıyla birlikte doğal yapısal çevreye saygılı ekolojik mekan üretim örneklerinin arttırılması gerekmektedir. Bu çerçevede tüketime hizmet eden tasarımların üretilmesi bir takım metalar olarak; çevremizdeki insan arzularını karşılayan nesnelerdir, ayrıca sembolik değerlerle de müşteri memnuniyetine servis edilen alanlardır. Bu post modern sembolik değer anlayışı; tasarım yapılan nesneyi ifade ederken, değişim değeri onun ticaretini ve işletmesini ifade etmektedir. Mimari tüm ürünler tanımı gereği, insanların yaşamları için tasarlanıp inşa edilmektedir. Ancak ortaya çıkan tasarım ürünü sadece estetik değil, etrafındaki doğayla da iç içe planlanmalı ve çevresel sürdürülebilirliği desteklemelidir.

Üniversite kampüslerinde tasarlanarak inşa edilen restoran ve kafeterya gibi; ekonomik boyutuyla tüketimi, sosyal boyutuyla etkileşimi temsil eden mekân örnekleri özellikle kamusal işlevlerle bütünleşmiş durumdadır. Bu önemli özellikleriyle özellikle genç neslin yaşamında ağırlık merkezi olma niteliğiyle konu önem arz etmektedir. Konuya katkı sunmak üzere doğal çevreye saygılı, ağaç kesmemeye gayret edilerek tasarlanan kafeterya örneğinde gençlerin sosyal ve mekânsal taleplerini karşılamak esas alınmıştır.

$\mathrm{Bu}$ anlamda konu ele alındığında özellikle mekânsal tasarım sadece bir fonksiyon veya estetik değil, insanların faaliyetlerini destekleyen, biçimlendiren aynı zamanda da yaşam tarzını belirleyen argümanlardır. Sosyal hayatı destekleyen yönüyle tasarımın önemi düşünülürse; tasarımcıların doğayla iç içe, kentin ekolojik dokusuna katkı sunan sürdürülebilir mimari tasarımlar yapmaya özen göstermeleri gerekmektedir.

\section{Teşekkür}

Projenin hayata geçirilmesinde Fırat Üniversitesi Rektörlüğü, Mimarlık Fakültesi Dekanlığı ve Yapı İşleri Daire Başkanlığı'na teşekkür ederiz. Projeyi H.P. tasarlamış, makaleyi H.P ve N.A.A. yazmıştır.

\section{Kaynaklar}

[1] Harvey, D. (2013), Sosyal Adalet ve Şehir, Çev.: Moral1, Metis Yay., İstanbul.

[2] Toffler, A. (1970), Future Shock, Toronto: Bantam Book

[3] Jencks, C. (1987), What is Post Modernism?, New York: Academy Edition

[4] Öncü, A. \& Weyland, P. (2013), Mekân, Kültür, İktidar-Küreselleşen Kentlerde Yeni Kimlikler, İletişim Yay., İstanbul.

[5] Adorno, T.W. (2012), Kültür Endüstrisi, Çev. N.Ülner, M.Tüzel, E.Gen, 7.Bask1, İletişim Yay., İstanbul.

[6] Ahlava, A. (2002), Architecture in Consumer Society, The University of Art and Design. Ylioppistopaino. Helsinki. Finland.

[7] Sloan, D. (2004), Culinary taste: Consumer Behaviour in the International Restaurant Sector, Routledge.

[8] Sözen, M. \& Tanyeli, U. (1986), Sanat Kavram ve Terimleri Sözlüğ̈̈, Evrim Matbaac1lık, İstanbul.

[9] Urry, J. (1995), Consuming Places, London and New York: Routledge.

[10] Mansvelt, J. (2005), Geographies of Consumption, SAGE Publications Ltd. London.

[11] Bell, D. \& Valentine, G. (1997), Consuming Geographies, London; New York: Routledge.

[12] Heung, V. \& Gu, T. (2012), Influence of restaurant atmospherics on patron satisfaction and behavioral intentions, International Journal of Hospitality Management, 31, 1167-1177.

[13] Ryu, K. (2005), Dinescape, emotions and behavioral intentions in upscale restaurants, Kansas State University.

[14] Kivela, J.J. (1997), Restaurant marketing: selection and segmentation in Hong Kong, International Journal of Contemporary Hospitality Management, 9(3), 116-123. 